\title{
Efektivitas Program No Lost Generation UNICEF dalam Menangani Kasus Child Soldiering di Konflik Suriah Tahun 2011-2018
}

\author{
Venisa Yunita Sari ${ }^{1}$ \\ ${ }^{1}$ Ilmu Hubungan Internasional, Fakultas Ilmu Sosial dan Ilmu Politik, Universitas Tanjungpura, \\ Jl. Prof. Dr. H. Hadari Nawawi, Bansir Laut, Kota Pontianak, Kalimantan Barat 78124
}

Penulis untuk Korespondensi/E-mail: venisayunita@student.untan.ac.id

\begin{abstract}
Abstrak
United Nations Children's Fund (UNICEF) adalah organisasi internasional bekerja di 191 negara yang berfokus pada penegakan dan perlindungan hak-hak anak. UNICEF melalui program No Lost Generation Initiative yang bertujuan untuk menyelamatkan tentara anak dan melindungi keselamatan anak di Suriah. Tujuan penelitian ini adalah untuk mengetahui tingkat efektivitas dalam pencapaian program bantuan yang diberikan oleh UNICEF melalui program No Lost Generation (NLG). Melalui metode deskriptif dengan pendekatan kualitatif, sumber data dalam tulisan ini berasal dari studi pustaka dengan telaah buku, jurnal ilmiah, laporan, serta artikel dari sumber terpercaya. Penelitian ditelusuri dengan menggunakan teori efektivitas organisasi yang dikemukakan oleh S.P. Siagian yang selaras dengan tujuan penelitian untuk menganalisis efektivitas suatu program organisasi internasional. Penulis menemukan bahwa program UNICEF No Lost Generation tahun 2011-2018 telah efektif dalam membantu aktor pemerintah untuk memenuhi, menegakkan, dan melindungi hakhak anak di Suriah melalui enam indikator, yaitu adanya kepastian tujuan NLG yang hendak dicapai, $N L G$ memiliki kepastian strategi, proses analisis dan perumusan kebijakan NLG yang baik, penyusunan NLG yang matang, tersedianya sarana dan prasarana yang memadai, sistem monitoring dan pengelolaan dalam implementasi NLG yang baik.
\end{abstract}

Kata kunci: No Lost Generation, UNICEF, Tentara Anak di Suriah

\begin{abstract}
The United Nations Children's Fund (UNICEF) is an international organization working in 191 countries that focuses on upholding and protecting children's rights. UNICEF through the No Lost Generation Initiative program which aims to save child soldiers and protect the safety of children in Syria. The purpose of this research is to determine the level of effectiveness in achieving the aid program provided by UNICEF through the No Lost Generation (NLG). Through a descriptive method with a qualitative approach, the data sources in this paper are based on literature studies consisting of books, scientific journals, reports, and articles from reliable sources. The research was traced by using the organizational effectiveness theory proposed by S.P. Siagian which is aligned with the research objectives to analyze the effectiveness of an international organization program. The author finds that the UNICEF No Lost Generation program 2011-2018 has been effective in helping government actors to fulfill, enforce, and protect children's rights in Syria through six indicators, namely the certainty of NLG's goals to be achieved, NLG has certainty in strategy, NLG has a good process analysis and formulation of policies, NLG has a mature preparation, availability of adequate facilities and infrastructure, monitoring and management systems in good NLG implementation.
\end{abstract}

Keyword: No Lost Generation, Syrian's Child Soldiering, UNICEF 


\section{PENDAHULUAN}

Perekrutan tentara anak (child soldiering) bukanlah suatu isu yang baru di dunia internasional. Permasalahan ini banyak ditemukan hampir di setiap konflik bersenjata yang melibatkan anak-anak sebagai tentara seperti di kawasan regional Timur Tengah, termasuk Suriah. Konflik bersenjata di suatu negara akan menjadi fokus perhatian dunia internasional, karena tentunya konflik tidak hanya merugikan negara yang bersangkutan, tetapi juga merugikan negara yang berkonflik. Perempuan dan anak-anak menjadi sasaran yang paling rentan dalam konflik bersenjata di masyarakat sipil. Hal tersebut diperburuk dengan perekrutan paksa anak-anak ke dalam angkatan bersenjata.

Konflik Suriah merupakan salah satu konflik di kawasan Timur Tengah yang timbul sebagai efek domino dari konflik Arab Spring atau Musim Semi Arab pada tahun 2011. Konflik tersebut mengancam eksistensi pemerintahan Presiden Bashar al-Assad. Rakyat Suriah menuntut pemerintah Suriah untuk berubah menjadi negara demokrasi. Tuntutan tersebut pun berujung pada perang sipil yang terjadi antara pihak pro pemerintahan dan oposisi. Setelah melihat rakyat dari negara Tunisia, Mesir, dan Libya berhasil menggulingkan presidennya, masyarakat Suriah yang mendukung demokrasi optimis dengan melakukan unjuk rasa terhadap Dinasti Assad yang terjadi sejak Hafizh al-Assad berkuasa pada 1971. Munculnya proses demokrasi disebabkan oleh lemahnya pembangunan ekonomi, kurangnya kebebasan di Suriah yang merupakan bagian dari pemisahan kekuasaan dari Bashar al-Assad (Muhammad, Yani, \& Sudirman, 2020).

Suriah merupakan salah satu negara yang terletak di sepanjang pantai Laut Tengah antara Asia Kecil dan Mesir (Isawati, 2018, p. 38). Jauh sebelum awal mula konflik Suriah dimulai, sudah banyak muncul berbagai permasalahan di Suriah tentang tingginya tingkat pengangguran, maraknya praktik korupsi, kurangnya kebebasan politik dan demokrasi di bawah Presiden Bashar al-Assad.

Masyarakat Suriah menjelaskan bahwa situasi politik tidak stabil sejak kemerdekaan Suriah pada tahun 1946. Hal ini disebabkan hubungan yang buruk antara sosialisme, agama dan kelompok politik. Akibat dari gejolak politik, rakyat Suriah menggelar demonstrasi pada Maret 2011 yang juga disebabkan berhasilnya perlawanan Tunisia, Mesir, dan negara-negara Timur Tengah lainnya kepada pemerintah. Protes publik berskala besar ini bertujuan untuk mengakhiri rezim Assad yang telah berlangsung selama lebih dari 40 tahun dan mengubah sistem pemerintahan menjadi negara demokrasi. Di bawah kepemimpinan Presiden Bashar alAssad, pemerintah Suriah menumpas protes dengan kekuatan dan kekerasan. Namun, inilah titik awal munculnya kelompok oposisi dan pemberontak pemerintah pada Juli 2011. (Fitria, 2017)

Kemudian, pembelot dari militer Suriah mengumumkan pembentukan Tentara Pembebasan Suriah, yakni sebuah kelompok yang bertujuan menggulingkan pemerintah. Hal tersebut memberikan dampak berkelanjutan menjadi perang saudara yang melibatkan negara luar turut berpartipasi dalam konflik tersebut. Walaupun demikian, pemerintah Suriah telah menolak untuk mengusulkan pencopotan pemerintahan yang saat ini menjabat dalam diskusi perdamaian tahun 2012 di Jenewa. Akibat kemunculan ISIS, situasi konflik Suriah semakin parah, dan organisasi tersebut berhasil menetapkan Raqqa sebagai ibu kota secara de facto (Fitria, 2017)

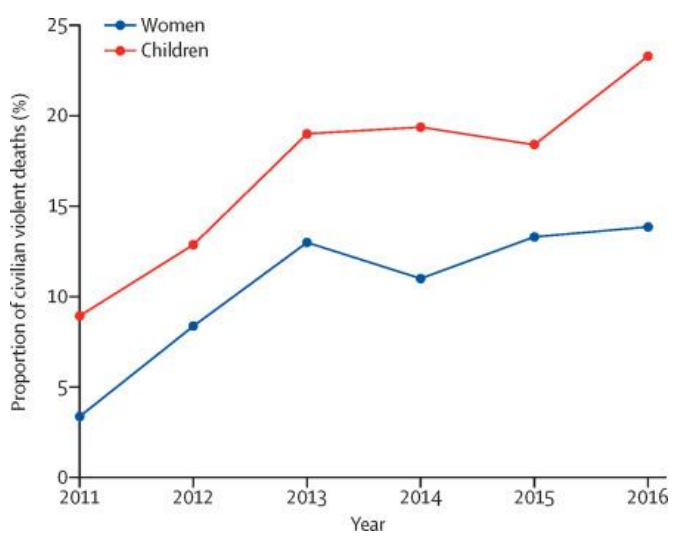

Gambar 1. Grafik Proporsi kematian akibat kekerasan sipil yang terdiri dari wanita dan anakanak dalam konflik Suriah tahun 2011-2016 ( (Sapir, D. G et all, 2018)

VDC adalah organisasi non-pemerintah nirlaba yang terdaftar di Swiss yang melacak dan mendokumentasikan pelanggaran hak asasi manusia dari konflik bersenjata di Suriah sejak 
18 Maret 2011, termasuk kematian terkait perang dan orang hilang, serta ditahan. Dalam menjalankan dokumentasi pelanggaran hak asasi manusia, VDC menerapkan standar internasional. (Sapir, D. G et all, 2018)

Untuk memastikan independensi dan netralitas, VDC hanya menerima pendanaan dari entitas yang independen, tidak bias, atau netral. VDC didirikan oleh Razan Zeitouna, seorang pengacara hak asasi manusia yang kemudian diculik bersama suaminya dan dua anggota staf VDC lainnya pada Januari 2013 di Duma, Suriah. Sejak itu, VDC dipimpin oleh sekelompok administrator di dalam dan di luar Suriah (awalnya di Turki dan kemudian Swiss) dan dua manajer basis data. Tergantung pada periode, VDC memiliki tim yang terdiri dari 3035 penyelidik dan jaringan lapangan yang mencakup setiap gubernur yang terdiri dari lebih dari 30 wartawan lapangan yang terlatih secara internasional, VDC mengumpulkan informasi tentang setiap kematian yang ditangkap oleh jaringan pelaporan daratnya (Sapir, D. G et all, 2018).

Berdasarkan grafik pada Gambar 1 dapat diamati bahwa konflik Suriah menuntut peningkatan proporsi anak-anak di antara kematian warga sipil karena pertempuran terus berlanjut, hingga dan termasuk tahun 2016 (Gambar 1). Sepanjang konflik, proporsi kematian di kalangan anak-anak lebih tinggi daripada proporsi kematian di kalangan perempuan, dan kesenjangan antara kedua proporsi ini mencapai maksimumnya pada tahun 2016 (Gambar 1) (Sapir, D. G et all, 2018). Perang Suriah terus berlanjut hingga pada 2018.

Data dari lembaga United Nations Children's Fund (UNICEF) menyebutkan konflik yang terjadi di Suriah telah menyebabkan sebanyak 1.106 anak-anak tewas dalam pertempuran di mana jumlah tersebut paling banyak sejak meletusnya perang saudara tersebut. Akibatnya, anak-anak tersebut terpaksa mengungsi ke negara tetangga Suriah seperti Turki, Lebanon, Irak, Yordania dan Mesir. UNICEF didirikan pada tahun 1953 dan secara resmi bergabung dengan Perserikatan Bangsa-Bangsa (PBB). Saat ini, UNICEF beroperasi di 190 negara dan wilayah di seluruh dunia (UNICEF, 2011).

Risnain berpendapat bahwa dari segi psikologis, merekrut anak untuk menjadi tentara dalam konflik bersenjata sangat berbahaya dan tidak kondusif bagi kepentingan anak. Kemudian, anak-anak yang direkrut tersebut ditanamkan kebencian kepada orang-orang yang tidak sesuai dengan identitasnya. Dalam kurikulum sekolah terdapat topik-topik khusus tentang terorisme dan jihad, serta diajarkan strategi tempur dan menanamkan kebencian, balas dendam dan permusuhan. (Risnanin, 2014)

Ditinjau dari sisi hak asasi manusia (HAM), Perekrutan tentara anak merupakan pelanggaran internasional, dan pelanggaran hak asasi anak adalah untuk kepentingan kelompok. Ketika anak-anak direkrut menjadi tentara, mereka kehilangan hak-hak anak, seperti hak atas pendidikan, hak untuk menerima cinta orang tua, dan hak untuk bermain dengan teman sebayanya. Bahkan, saat merekrut tentara anak, mereka kerap mengalami kekerasan fisik dan psikis, termasuk kekerasan seksual (Risnanin, 2014).

Oleh karena itu, diperlukan partisipasi semua pihak untuk terlibat dalam menangani permasalahan tersebut, salah satunya organisasi internasional. United Nations (UN) melalui salah satu badannya, yakni UNICEF ikut serta dalam menangani perekrutan tentara anak-anak korban konflik di Suriah, di mana UNICEF menyerukan perlindungan terhadap anak-anak Suriah agar mereka mendapatkan tempat yang aman dari konflik tersebut, salah satunya melalui program No Lost Generation Initiative (لا لضياع جيل) (Alam, 2018). Berdasarkan penjelasan yang telah terurai di atas mengenai beberapa literatur yang membahas tentang UNICEF, Child Soldiering, dan Konflik Suriah. Untuk itu, penelitian ini mengangkat rumusan masalah "Apakah program No Lost Generation UNICEF berjalan dengan efektif dalam menangani child soldiering di Suriah?".

\section{METODE PENELITIAN}

Metode yang digunakan dalam penelitian ini adalah metode penelitian deskriptif, yaitu metode penelitian yang menjelaskan bagaimana keadaan secara objektif kemudian dilanjutkan dengan interpretasi data agar dapat menjelaskan atau menganalisis masalah serta memberikan jawaban terhadap keefektifan program No Lost Generation (NLG) milik United Nations Children's Fund (UNICEF) dalam mengatasi 
child soldiering pada konflik Suriah tahun 20112018.

Kemudian, level analisis yang digunakan penulis pada penelitian ini adalah perilaku kelompok. Level analisis perilaku kelompok menganggap bahwa kelompok lebih memberikan pengaruh dalam dunia internasional dibandingkan dengan individu. Teknik yang digunakan untuk menganalisis fenomena dalam penelitian ini diperoleh melalui studi kepustakaan, yakni dengan merujuk pada buku-buku, jurnal, artikel, surat kabar, beritaberita lain dari media yang relevan. Ruang lingkup penelitian yang ingin penulis paparkan adalah mengenai United Nations Children's Fund (UNICEF) dalam mengatasi Child Soldiering diawali pada awal dicanangkannya program No Lost Generation, yakni tahun 2011 sampai 2018. Oleh karena itu, penulis melengkapi dan mengkaji bahannya dari dukungan data mulai tahun 2011-2018.

\section{HASIL DAN PEMBAHASAN}

\section{Faktor-Faktor Penyebab Konflik Suriah}

Menurut Fahham and Kartaatmaja (2014) terdapat dua faktor utama pemicu konflik di Suriah. Pertama, faktor internal, seperti masalah sosial, ekonomi, dan politik dalam berupa tingginya pengangguran, tingginya inflasi, terbatasnya mobilitas sosial, merajalelanya korupsi, tidak adanya kebebasan politik, represifnya aparat keamanan. Hafizh al-Assad melanjutkan kebijakan era Bashar al-Ashad. Perubahan terjadi pada masa kepresidenan Hafizh al-Assad. Misalnya, posisi tentara Suriah di Lebanon, karena biaya operasi militer, adalah Di bawah kepemimpinan pemerintah, tentara Suriah telah ditarik dari negara dan kebutuhan rakyat. Libanon mencegah Suriah mencampuri masalah negaranya. Tentara keamanan Suriah dibayar sebesar US\$ 40 sehari untuk mematamatai segala aktivitas dan menghabiskan sepertiga anggaran belanja negara untuk kebutuhan militer. Suriah mengalokasikan anggarannya sebesar 50 persen untuk memenuhi kebutuhan pasukan militer daripada kesejahteraan rakyatnya.

Permasalahan lainnya adalah faktor ekonomi. Pada masa pemerintahan Hafizh al-Assad dan Bashar al-Assad, situasi perekonomian di Suriah mengalami permasalahan diakibatkan oleh kondisi rezim yang penuh dengan korupsi dan maraknya praktik suap di antara pegawai pemerintahan yang mengakibatkan terjadinya krisis ekonomi bagi rakyat Suriah. Pada pemerintahan Hafizh al-Assad banyak permasalahan seperti, korupsi, kelebihan tenaga kerja yang tidak sesuai dengan jumlah lapangan kerja, pengelolaan keuangan negara yang tidak tepat guna yang menyebabkan perekonomian Suriah tertinggal jauh dengan negara-negara lainnya. Pendapatan Lebanon yang mencapai angka 3.000 dollar, dan Israel 17.000 dollar sedangkan Suriah hanya sekitar 1.000 dollar. Jumlah pengangguran diperkirakan sekitar 22 persen dan hampir 50 persen dari anggaran digunakan untuk pembiayaan militer dan pasukan keamanan. Hal tersebut semakin parah dengan terbatasnya sumber daya alam, jumlah militer yang terlalu besar, berkurangnya bantuan luar negeri, korupsi, dan pertumbuhan penduduk yang tinggi (Ridho, Yani, \& Sudirman, 2020).

Kondisi perekonomian Suriah pada saat Bashar al-Assad yang berkuasa sangat buruk. PDB per kapita turun selama 1980 hingga tahun 1990. Kemudian, Bashar al-Assad menjanjikan akan melakukan reformasi ekonomi. Pada tahun 2005, Bashar al-Assad memperkenalkan reformasi ekonomi dengan istilah ekonomi pasar sosial yang mengalihkan perekonomian yang dikelola oleh pemerintah menjadi perekonomian liberal. Namun, liberalisasi ekonomi hanya memberikan kemakmuran pada sejumlah kota besar seperti Damaskus dan Aleppo, tidak merata pada daerah-daerah kecil atau kota-kota lain. Sistem ekonomi Suriah dikendalikan oleh tiga kelompok. Pertama, manajer sektor publik, pengusaha kecil dan kelompok perlindungan bisnis 77 juga merupakan anggota kelompok keamanan dan militer. Kelompok-kelompok ini menikmati hak istimewa dalam ekonomi Suriah. Produksi minyak harian pada tahun 2010 hanya 385.000 barel, jauh lebih rendah dari 583.000 barel pada tahun 1996. Di bawah kepemimpinan pemerintahan Bashar al-Assad, banyak industri produktif yang mampu menyerap tenaga kerja muda dalam jumlah besar dibongkar, sehingga angka pengangguran usia kerja terus meningkat.

Kedua, faktor eksternal, yaitu terdapat kepentingan politik dan ekonomi negara luar Suriah. Negara Suriah selama di bawah pemerintahan al-Assad bersekutu dengan Rusia 
dan Iran. Akan tetapi, terdapat juga beberapa negara yang menjadi pihak oposisi Suriah. Misalnya, Turki yang ikut campur dalam konflik Suriah karena ingin menjadi pemain utama di Timur Tengah. Di saat yang sama, negaranegara Barat tertarik dengan sumber daya alam gas Suriah ( Fahham \& Kartaatmaja, 2014). Negara Amerika Serikat (AS) merupakan salah satu contohnya. Sebagai negara adidaya yang menjunjung tinggi nilai-nilai demokrasi dan hak asasi manusia, Amerika Serikat tentunya mengutuk keras segala bentuk kerja sama antara Rusia dan Suriah, menurutnya hal tersebut dapat mengancam keamanan internasional semua negara di dunia. Dukungan penuh Rusia kepada pemerintah Suriah kemudian mengganggu Amerika Serikat. Hal tersebut menyebabkan Amerika Serikat telah menetapkan wilayah timur sejak awal konflik Suriah. Timur Tengah merupakan salah satu wilayah prioritas dalam politik luar negeri dan kepentingan nasional AS (Deovanka \& Zulian, 2020).

\section{Latar Belakang Munculnya Tentara Anak di Suriah}

Konflik Suriah yang berlangsung sejak tahun 2011, menyebabkan bertambahnya korban jiwa. Dilansir dari laman Republika, menurut data SNHR, terdapat sebanyak 6.964 warga sipil yang tewas di Suriah pada 2018. Jumlah ini terus mengalami peningkatan cukup tajam dari tahuntahun sebelumnya yang masih tidak mencapai 250 ribu jiwa. Kondisi ini mengakibatkan sebanyak 7 juta orang di Suriah mengalami kerentanan pangan dan pengangguran (Mukhtar \& Nashrullah, 2019).

Perang Suriah terus berlanjut menewaskan banyak orang dewasa, sehingga menyebabkan tenaga kerja dewasa semakin berkurang. Oleh karena itu, para oknum perang pun mengambil anak-anak di daerah konflik untuk dipaksa ikut menjadi tentara. Pada tahun 2016 dilaporkan ada sebanyak 851 anak-anak direkrut menjadi tentara anak-anak di Suriah. Pada tahun yang sama pula, 652 anak meninggal dan 647 menderita kecacatan, dan jumlah ini meningkat dengan cepat. Pada Januari dan Februari 2018, tercatat ada 1.000 anak tewas atau terluka dalam konflik Suriah (Turner, 2018).

Penulis menilai terdapat hidden agenda dibalik perekrutan tentara anak ini selain dikarenakan oleh kurangnya tenaga kerja orang dewasa. Dengan direkrutnya anak-anak menjadi tentara dapat mengurangi anggaran pengeluaran kelompok. Hal ini dikarenakan anak-anak tidak memerlukan biaya hidup yang lebih besar daripada orang dewasa. Kelompok teroris, oposisi pemerintah, dan pemerintah memanfaatkan anak-anak karena mereka adalah sosok yang mudah didoktrin dan dimanipulasi, murah, dan pejuang garis depan yang mudah digantikan. Adapun dari mereka yang terpaksa direkrut menjadi tentara sebagai pilihan untuk bertahan hidup.

Meskipun semua faksi dalam konflik Suriah telah merekrut tentara anak, belum diketahui dengan jelas apakah unit formal yang hanya terdiri dari anak di bawah umur (individu di bawah usia 18) telah dibentuk oleh salah satu faksi bersenjata dalam perang, dengan kemungkinan pengecualian dari Islam Kelompok negara (juga dikenal sebagai ISIS). Di luar kelompok Negara Islam, anak-anak yang berperang dalam konflik sering melakukannya dalam formasi tidak teratur yang tidak memiliki struktur pangkat normal, atau aktif dalam asosiasi pemuda pra-perang yang sejak itu menjadi militer. Sebagian besar dari mereka menjadi sukarelawan dalam perang (Mutter, 2015).

Dalam konflik Suriah menyumbang banyak korban eksploitasi, kekerasan, penganiayaan, dan kejahatan terhadap anak-anak. Beberapa penyebab terbunuhnya anak-anak di Suriah disebabkan oleh pembunuhan dengan sengaja, penyiksaan, dan kekerasan berdasarkan gender. Selain itu, terjadinya pengungsian paksa telah meningkatkan pernikahan dini, perdagangan manusia, kerja paksa anak, dan pemisahan anak dari keluarganya. Akibatnya, anak-anak ini berada di bawah tekanan psikologis dan membutuhkan kesehatan mental serta dukungan layanan. Fenomena ini tidak lepas dari pengaruh UNICEF, salah satu organisasi internasional yang terlibat dalam penyelesaian masalah ini. UNICEF merupakan organisasi internasional yang berfokus pada perlindungan anak-anak dan wanita di dalam ataupun di luar kondisi konflik.

\section{United Nations Children's Fund (UNICEF)}

UNICEF adalah organisasi yang didedikasikan untuk melindungi hak-hak anak di bawah naungan Perserikatan Bangsa-Bangsa. Pada 11 
Desember 1946, Sidang Umum PBB mengumumkan bahwa mereka akan mencari solusi terbaik di negara-negara yang membutuhkan sesuai dengan Pasal 55 Piagam PBB. Dalam menjalankan misinya, UNICEF mendapatkan dana penuh dari kontribusi sukarela oleh individu, lembaga, perusahaan, NonGovernmental Organization (NGO's), dan pemerintah suatu negara. UNICEF berpegang teguh pada Konvensi Hak Anak (KHA) dan memperjuangkan terbentuknya hak anak yang memiliki prinsip etika, serta berstandar internasional (UNICEF, 2015). UNICEF memiliki kekuatan global untuk memengaruhi pembuat keputusan dan lembaga utama lainnya untuk mewujudkan ide paling inovatif menjadi kenyataan. UNICEF percaya bahwa membesarkan dan merawat anak adalah tulang punggung kemajuan generasi umat manusia ini. UNICEF berkomitmen untuk menyelesaikan masalah kemiskinan, kekerasan, penyakit dan diskriminasi terhadap anak (Sirait, 2014, p. 6).

UNICEF turut melaporkan terdapat sekitar 300 ribu anak berusia di bawah usia 18 tahun yang telah direkrut dan dieksploitasi menjadi tentara anak (child soldiers) pada sekitar 30 daerah konflik di seluruh dunia, salah satunya di Suriah (Pikiran Rakyat, 2018). Dalam konteks ini, UNICEF, sebagai aktor utama dalam promosi prakarsa "No Lost Generation", bertujuan untuk mendapatkan sumber publisitas dan mobilisasi yang efektif untuk program perlindungan anak. Program ini juga mencakup hak-hak anak berkebutuhan khusus, dan dukungan untuk mencegah anak terpisah dari orang tua atau keluarganya (Fitria, 2017).

UNICEF hadir di tengah konflik Suriah dengan memberikan bantuan No Lost Generations pada tahun 2013. Program tersebut mencakup tiga bidang utama, yaitu pendidikan, perlindungan anak (untuk usia di bawah 18 tahun) dan remaja dan remaja usia 10-19 tahun (untuk usia 15-24). Diharapkan melalui program ini dapat mengatasi perekrutan tentara anak dan memberikan pelayanan psikologis, serta memberikan advokasi bagi anak-anak yang pernah bergabung menjadi tentara atau terkena dampak krisis.

\section{Organisasi Internasional}

Organisasi internasional merupakan konsep yang berasal dari perspektif liberalisme. Perspektif liberalisme memandang bahwa hakikat dari umat manusia adalah sosok yang baik dan percaya akan perdamaian sejati yang dapat diwujudkan melalui kerja sama (Hennida, 2015 , p. 7). Sumaryo Suryokusumo menyatakan bahwa organisasi internasional adalah suatu proses; organisasi internasional juga memerhatikan aspek perwakilan dari tingkat proses yang dicapai pada waktu tertentu. Dalam kerangka kerja sama, organisasi internasional juga dibutuhkan untuk menyesuaikan dan menemukan kompromi untuk menentukan kesejahteraan dan menyelesaikan masalah bersama serta mengurangi perselisihan. (Malahayati, 2015)

Teuku May Rudy menyatakan bahwa pengertian organisasi internasional adalah model kerja sama yang didasarkan pada struktur organisasi yang jelas dan lengkap yang melintasi batas negara, dan diharapkan dapat dilaksanakan dan diproyeksikan secara berkelanjutan dan kelembagaan. Fungsinya adalah untuk mencapai tujuan yang perlu dan disepakati antara pemerintah dan organisasi non-pemerintah atas dasar negara yang berbeda (Malahayati, 2015).

Variasi-variasi di dalam organisasi internasional ditentukan oleh: (1) jumlah negara yang terlibat; (2) mekanisme pengambilan keputusan; (3) cakupan isu yang menjadi tanggung jawab atau ruang lingkup kerjanya; (4) derajat kontrol yang sentral; (5) derajat fleksibilitas dalam organisasi; (6) memiliki mekanisme pelepasan diri atau alasan untuk melepaskan diri. (Hennida, 2015)

\section{Analisis Efektivitas UNICEF No Lost Generation Initiavtive (NLG) 2011-2018 dalam Menangani Perekrutan Tentara Anak di Suriah}

Berdasarkan beberapa variabel dalam judul, penulis memfokuskan pada variabel organisasi internasional, diantaranya adalah UNICEF menganalisis parameter efektivitasnya. Evektifitas didefinisikan oleh para ahli dengan berbeda-beda persepektif tergantung pada pendekatan yang digunakan oleh masingmasing ahli. Organisasi biasanya berada dalam lingkungan yang bergejolak dengan sumber daya yang terbatas. Lingkungan ini akan berubah seiring waktu, dan perubahan ini akan memengaruhi keefektifan organisasi. Agar organisasi dapat mempertahankan kelangsungan hidup dan fungsinya, maka organisasi harus efektif. Menurut Amitav Etzioni, efektivitas 
adalah suatu keadaan yang memperlihatkan sejauh mana rencana dapat tercapai oleh sebuah organsasi. Semakin banyak rencana yang dapat dicapai, semakin efektif pula kegiatan organsasi tersebut, sehingga kata efektivitas dapat juga diartikan sebagai tingkat keberhasilan yang dapat dicapai dari suatu cara atau usaha tertentu sesuai dengan tujuan yang hendak dicapai (Pattihua, 2017, p. 521).

Definisi efektivitas telah dikemukakan oleh Sondang P. Siagian. Beliau mengartikan efektivitas adalah sebuah pemanfaatan segala sumber daya yang ada, beserta sarana dan prasarananya dalam kuantitas tertentu yang sebelumnya secara sadar ditentukan untuk menghasilkan sejumlah barang atas jasa kegiatan yang dijalankannya (Erdina \& Hariani, n.d.). Efektivitas memperlihatkan keberhasilan dari segi tercapai tidaknya sasaran yang telah ditetapkan yang dapat diukur dengan 6 indikator, yaitu (1) Kepastian tujuan yang hendak dicapai; (2) Kepastian strategi untuk pencapaian tujuan; (3) Proses analisis dan perumusan kebijakan yang baik; (4) Penyusunan program yang matang; (5) Tersedianya sarana dan prasarana yang memadai untuk memudahkan pencapaian tujuan; dan (6) Adanya sistem monitoring dan pengelolaan dalam implementasi rencana kegiatan (Widyawati \& Widiani, 2019).

Untuk itu keefektifan program UNICEF dapat dikaji menggunakan teori efektivitas organisasi karena UNICEF itu sendiri dapat digolongkan sebagai organisasi internasional. Menurut K. J Holsti mengemukakan secara teknis organisasi internasional memiliki tiga peran utama di antaranya (Ikbar, 2014):

1. Sebagai instrumen (alat). Dalam hal ini organisasi menjadi alat untuk memenuhi kepentingan anggotanya meskipun adanya pembatasaan kekuasaan negara untuk bertindak secara otonom.

2. Sebagai arena (forum). Organisasi sebagai wadah yang menjadi tempat pertemuan bagi negara anggotanya untuk berdiskusi, berargumentasi, dan bekerja sama.

3. Sebagai aktor. Organisasi internasional sebagai aktor independen yang memiliki kesempatan untuk menjadi setara dengan negara. Sehingga, organisasi internasional bisa bertindak sendiri tanpa takut dipengaruhi secara signifikan oleh aktoraktor lainnya.

UNICEF berperan aktif dalam mengatasi perekrutan tentara anak dalam konflik Suriah. Bentuk intervensi kemanusian UNICEF, seperti No Lost Generation (NLG), berhasil memberikan dampak positif agar keberlangsungan hidup dan kebutuhan anakanak serta pemuda Suriah tetap didapatkan, terutama di bidang pendidikan. Seluruh program yang dilakukan oleh NLG ataupun mitranya ditargetkan untuk melingkupi kriteria program yang telah disepakati bersama dan dikalkulasikan ke dalam tiga pilar utama, yaitu pendidikan, perlindungan anak, serta remaja dan pemuda. UNICEF sebagai organisasi internasional menjalankan peranannya, seperti K. J Holsti (Ikbar, 2014):

1. Sebagai instrumen (alat). Dalam hal ini UNICEF menjadi alat untuk memenuhi kepentingan anggotanya melalui keputusan dan kebijakan-kebijakannya yang otonom dan koheran, meskipun adanya pembatasaan kekuasaan negara untuk bertindak secara otonom. UNICEF menjalankan peranannya sebagai alat (instrumen) anggota-anggotanya dalam mencapai kepentingannya, yakni ingin mencegah adanya perekrutan tentara anak dan melindungi anak-anak di Suriah dari dampak krisis. Untuk mencapai tujuannya, UNICEF mencoba berbagai cara dalam mengintervensi konflik di Suriah melalui berbagai program yang dicanangkannya.

2. Sebagai arena (forum). Peran UNICEF sebagai arena adalah melalui menjalin kerja sama dengan organisasi internasional, pemerintah, dan aktor lainnya, untuk mendidik para angkatan bersenjata di Suriah untuk mempromosikan perawatan yang lebih baik kepada anak-anak di area konflik. Hal ini dibuktikan dengan pada tahun 2015 UNICEF menambah perlindungan anak dan dukungan pelayanan psikososial untuk anak dan pengasuh melalui penambahan kapasitas rekan. Serta, bekerja sama dengan sektor pemerintah, NGO, dan bahkan individu. Pada sektor pemerintah, UNICEF telah berdiskusi dengan sejumlah negara untuk terlibat dalam penanganan krisis di Suriah. Pada tahun 2015, jumlah NGO yang bekerja sama dengan UNICEF mengalami 
peningkatan dua kali lipat dari tahun sebelumnya di mana yang awalnya 13 NGO menjadi 23 NGO. Tercatat adanya penambahan jumlah rekan kerja, yakni sebanyak 454 ribu anak-anak dan pengasuhnya mendapatkan dukungan psikososial terstruktur (UNICEF, 2015). UNICEF juga berinovasi mengajak individu untuk berpartisipasi dalam programnya, yakni melalui proyek penggalangan dana yang menggunakan blockchain bertajuk Game Changers.

3. Sebagai aktor. Di dalam setiap kebijakankebijakan yang dirancang berdasar pada kerangka-kerangka dan konsep-konsep yang dibentuk oleh UNICEF sendiri tanpa pengaruh dari negara atau pihak manapun. Seperti yang disampaikan oleh Clive Archer, organisasi internasional dapat berperan sebagai aktor independen terbukti di mana berbagai konsep dari kebijakan-kebijakan berdasar pada kerangka yang dibuat sendiri oleh UNICEF tanpa desakan dari pihak lain (Auliya \& Kusumawardhana, 2020).

Hal ini terlihat dari peranan UNICEF yang berhasil memengaruhi berbagai kebijakan para anggotanya untuk berfokus pada keberlangsungan hidup anak-anak dan utamanya terkait program NLG dan program-program lain yang berhubungan dengan NLG. Hal tersebut tercermin dari keberhasilan pada sektor pendidikan, setidaknya 1.053 .828 anak-anak di 9 provinsi telah mendapatkan pengetahuan bahaya sisa peledak dan 192 ribu remaja mendapatkan kesempatan untuk belajar dan berkembang dengan akses yang lebih baik. Selanjutnya sebanyak 4.272 melakukan pelatihan keterampilan pendidikan dasar, termasuk dukungan psikososial (OCHA, 2017).

Organisasi internasional dapat diteliti keefektifannya berdasarkan variabel-variabel yang ada pada organisasi tersebut. S.P. Siagian (1987) menyebutkan keefektifan program organisasi internasional dapat dibagi menjadi beberapa titik pandang analitis yang membedakan variabel struktural yang terkait dengan desain organisasi internasional tersebut yang terbagi menjadi 6 indikator, di antaranya (Widyawati \& Widiani, 2019):
Tujuan NLG yang memiliki kepastian.

Hal ini bertujuan agar para implementer dalam pelaksanaan tugas dapat mencapai sasaran yang terstruktur dan terarah, sehingga tujuan organisasi dapat tercapai. Tujuan didirikannya NLG adalah melindungi keselamatan dan masa depan seluruh generasi muda yang terkena dampak krisis Suriah, termasuk para korban perekrutan tentara anak-anak, agar mereka dapat menjalani kehidupan yang layak, terpelajar, dan terbina. Selain anak-anak di Suriah, program NLG juga dilaksanakan di lima negara lain, antara lain Turki, Lebanon, Yordania, Irak, dan Mesir. Hingga sekarang, NLG sudah menginjak dua fase, pertama pada tahun 2013 sampai 2015, sedangkan fase kedua dimulai pada tahun 2016 sampai 2018 (Alam, 2018). Pecahnya konflik Suriah pada tahun 2011 menjadi langkah awal pembuatan inisiatif ini.

Dalam fase I, dipaparkan seluruh program NLG dirangkum ke dalam tiga pilar utama, yakni terdiri dari pendidikan, perlindungan anak berusia di bawah 18 tahun, remaja berusia 10-19 tahun, dan pemuda yang berusia 15-24 tahun (No Lost Generation, 2016). Dalam skema No Lost Generation, fase II yang dikembangkan bersama oleh mitra operasional di tingkat regional menyatakan bahwa inisiatif tersebut akan berfungsi dengan baik sebagai kerangka kerja strategis yang diinformasikan oleh situasi saat ini, tetapi tetap fleksibel untuk menanggapi perubahan dinamika, di dalam wilayah Suriah dan pergerakan pengungsi di wilayah ini dan sekitarnya. Selanjutnya, pembentukan skema program No Lost Generation telah memungkinkan para pemangku kepentingan di luar sektor kemanusiaan untuk berkontribusi pada tujuan "Generasi Tidak Hilang" di fase II, termasuk perusahaan sektor swasta (terutama dari sektor teknologi), kelompok pelajar, dan warga negara secara individu (Alam, 2018).

Pada kedua fase tersebut, UNICEF telah menetapkan target yang hendak dicapainya, di antaranya: sejalan dengan No Lost Generation Initiative, UNICEF mendukung sistem nasional di Suriah dan di negara-negara penerima pengungsi Suriah yang menjangkau lebih dari 773.000 anak (98\% target) dengan dukungan psikososial, dan membantu lebih dari 3,2 juta 
anak (88\% target) untuk mendaftar di pendidikan formal. Dengan dukungan UNICEF, lebih dari 8,9 juta anak telah divaksinasi folio di Suriah, Yordania, Irak dan Mesir. Di Suriah, Yordania, Lebanon, dan Irak, lebih dari 6,8 juta orang memiliki akses berkelanjutan ke air bersih melalui sistem pasokan air yang lebih baik, dan 1,8 juta orang mendapat manfaat dari penyediaan air sementara (UNICEF, 2017).

\section{Kepastian strategi untuk pencapaian tujuan NLG.}

Strategi diperlukan agar para implementer tetap berada pada 'jalur' yang ditetapkan dalam upaya pencapaian tujuan. Berdasarkan pada prinsip kemanusiaan atau humanity initiative, program UNICEF No Lost Generation didasarkan pada beberapa strategi, yaitu: (1) Memastikan anakanak dan pemuda mempunyai akses untuk mendapatkan pendidikan berkualitas; (2) Meningkatkan akses berkualitas terhadap perlindungan anak pada wilayah tempat tinggal, serta pelayanan dukungan psikososial; (3) Memberikan dukungan pada remaja dan pemuda untuk berkontribusi terhadap ketahanan dan kohesi sosial dalam komunitas dan wilayahnya, seperti remaja dan pemuda dilibatkan dalam pencarian bukti, pembuatan program, serta advokasi dan peluang mata pencaharian; (4) meningkatkan kerja sama dengan sektor-sektor di luar pemerintah, seperti sektor swasta, NGO, lembaga-lembaga bilateral, dan badan-badan yang berada di bawah naungan Perserikatan Bangsa-Bangsa (PBB).

Inisiatif NLG juga mempunyai keterkaitan dengan dua program lainnya yang bergerak dalam bidang advokasi, pencari suaka, dan kemanusiaan bagi korban di negara-negara yang terkena krisis Suriah. NLG mempunyai keterkaitan dalam Regional Refugee and Resilience Plan (3RP), yaitu program melingkupi respons terhadap krisis Suriah di Irak, Mesir, Yordania, Lebanon, dan Turki. Di sisi lain, terdapat NLG yang berfokus pada anak-anak dan pemuda korban krisis Suriah mempunyai keterkaitan dengan Syria Humanitarian Response Plan (HRP) yang mencakup aksi kemanusiaan di dalam Suriah (OCHA, 2017).

\section{Proses analisis dan perumusan kebijakan NLG yang baik.}

Hal ini berhubungan dengan kemampuan rencana kegiatan sebagai penghubung yang tepat untuk mencapai tujuan. Proses analisis dan perumusan kebijakan telah dilakukan sejak UNICEF No Lost Generation dimulai. Dalam merumuskan kebijakan dan program, UNICEF mengadakan pertemuan tahunan melalui No Lost Generation Summit tahunan. UNICEF setiap tahunnya mengeluarkan Annual Report (Laporan Tahunan) terkait pelaporan perkembangan program No Lost Generation di Suriah. Laporan ini berupaya memberikan rekomendasi kepada para pendonor, pembuat kebijakan, peneliti dan pelaksana tentang bagaimana memfasilitasi peningkatan hasil pembelajaran bagi anak-anak dalam situasi krisis dan konflik. Sebagai studi pertama dari jenisnya sejak permulaan konflik di Suriah, laporan tersebut merupakan kesempatan unik untuk menilai secara kritis pengaruh praktik guru dan ruang belajar pada pembelajaran dan kesejahteraan anak di Suriah.

\section{Penyusunan program NLG yang matang.} Penyusunan sebuah program yang matang dilakukan setelah pelaksanaan proses analisis dan perumusan kebijakan. Perencanaan NLG dilakukan setelah UNICEF bersama Pemerintah Suriah melalui Menteri Pendidikan atau Minister of Education (MoE) melakukan analisis dari hasil pengumpulan data jumlah anak-anak korban krisis beserta fasilitas dan infrastruktur pendidikan yang patut diberikan. Perencanaan program yang dilakukan oleh UNICEF berdasarkan dari laporan data kebutuhan kemanusiaan di Suriah dengan panduan.

Analisis NLG berkaitan dengan sektor pendidikan di mana menggunakan tiga sumber data untuk memahami sektor pendidikan di Suriah: (1) Sensus sekolah tahunan dari Kementerian Pendidikan (MoE) di Damaskus, yang berisi angka-angka tentang fasilitas sekolah, siswa yang terdaftar dan staf sekolah; (2) Hasil survei dari 59 sekolah di wilayah kendali pemerintah. Survei tersebut menghasilkan kombinasi informasi faktual dan subyektif dari anak-anak dan orang dewasa; dan (3) Literatur yang relevan (laporan dan rencana implementasi) yang dibuat oleh badan-badan 
internasional, organisasi non-pemerintah (LSM) dan lain-lain, memberikan perspektif sektoral dan lintas sektoral yang lebih besar. Dokumen ini terutama membahas pendidikan dasar dan menengah (UNICEF, 2015).

Berdasarkan pada data yang telah didapatkan, NLG pada tahun 2016 sampai 2018 lebih sistematis jika dibandingkan dengan tahuntahun sebelumnya. Di mana NLG lebih memaksimalkan pemanfaatan sekolah publik, termasuk sekolah yang menerapkan doubleshift, kampanye Back to Learning, programprogram proteksi sosial lainnya. Respons dalam pilar perlindungan anak melebihi target, salah satunya persentase anak-anak lahir tanpa dokumen resmi berkurang dari sekitar 35 persen pada tahun 2012 menjadi 3 persen pada tahun 2016. Adanya sekitar 78.000 remaja dan pemuda terlibat atau bahkan memimpin inisiatif keterlibatan sosial, sipil, dan ekonomi (Alam, 2018). Di Suriah, partisipasi sekolah pada 20172018 meningkat dibandingkan 2016-2017, dari 3,7 juta menjadi 4,1 juta anak. Selain itu, lebih dari 520.000 anak baik di sekolah atau di luar sekolah mendapatkan manfaat dari program pendidikan non-formal yang diatur, seperti program belajar mandiri (No Lost Generation Initiative, 2019).

Tersedianya sarana dan prasarana yang memadai untuk memperlancar pencapaian tujuan NLG.

Dalam memudahkan pencapaian tujuan diperlukan adanya sarana dan prasarana yang baik. Di mana pemenuhan sarana dan prasarana yang baik berasal dari UNICEF dan tentunya juga dibantu oleh mitra-mitra yang bekerja sama dengan UNICEF Suriah, seperti pada sektor pendanaan dan sumber daya manusia. Intervensi kemanusiaan UNICEF melalui bantuannya pada tahun 2015 telah memberikan manfaat bagi 1,4 juta orang di daerah yang sulit dijangkau. Jumlah ini meningkat 193 persen selama tahun 2014, menunjukkan bahwa program kerja UNICEF di Suriah telah mencapai hasil yang positif. UNICEF Syria juga telah bekerja sama dengan berbagai negara dan menyediakan 61 persen dana dari Syria response plan fund. Dana ini berasal dari Amerika Serikat, Uni Eropa, Inggris, Kanada, Belgia, Jerman dan Jepang, serta donor non-tradisional dan donor umum lainnya dari Kuwait, Uni Emirat Arab dan Arab
Saudi (Fitria, 2017). Adanya peningkatan pendanaan dari pemerintah yang berpartisipasi akan membantu mempercepat upaya tersebut. Dana tersebut juga dapat merevitalisasi pekerjaan pasca konflik untuk membangun kembali kehidupan dan komunitas anak-anak.

Selain pendanaan dari pemerintah, UNICEF juga berusaha menggandeng aktor non-negara untuk turut aktif memberikan bantuan kepada para pengungsi Suriah. Salah satunya melalui proyek penggalangan dana yang menggunakan blockchain bertajuk Game Changers yang diluncurkan pada Februari 2017 lalu. Proyek tersebut bertujuan untuk membantu rakyat Suriah yang terkena dampak perang, terutama anak-anak. UNICEF mengundang para pemain game e-sports untuk secara aktif berpartisipasi dalam penambangan cryptocurrency. Gamer adalah aktivis dengan perangkat kartu VGA dengan kemampuan menambang. Semakin banyak pemain yang bergabung, semakin besar peluang untuk berdonasi (Kresnawan, 2017).

Alasan UNICEF menggunakan teknologi blockchain dikarenakan mereka melihat ada tiga keuntungan, yakni pertama, memperkenalkan cara baru untuk berdonasi. Kedua, menciptakan transparansi dana yang lebih besar dalam proses internal. Ketiga, meminimalisir adanya masalah transaksi pembayaran kepada mitra kerja. Manfaat utama dari sistem ini adalah memberikan kemudahan bagi organisasi dalam mengirim pembayaran langsung ke kontraktor tanpa memerlukan perantara dan bisa mengurangi 30 persen anggaran bantuan yang hilang akibat korupsi. Dilansir KumparanTECH, program Game Chaingers sejauh ini telah mengumpulkan uang virtual senilai lebih dari 900 Euro atau sekitar Rp 15,1 juta.

\section{Adanya sistem monitoring dan pengelolaan dalam implementasi NLG.}

UNICEF menyediakan proses pengawasan sistem informasi. Sistem rutin dan survei khusus telah menghasilkan data yang lebih terpilah berdasarkan wilayah, gender, tingkat ekonomi di mana dilaporkan melalui press release dan laporan tahunan. Hal tersebut memungkinkan analisis lebih lanjut untuk dapat berkontribusi pada peningkatan perencanaan program. Sebagaimana yang terlampir contoh data-data terpilah yang dapat dijadikan pertimbangan oleh 
pemerintah dan UNICEF dalam pengambilan kebijakan terhadap masyarakat setempat. Selain pengawasan yang dilakukan oleh UNICEF, pengawasan dan pengendalian juga dilakukan oleh Pemerintah Suriah pada pelaksanaan kegiatan, karena berjalannya program butuh persetujuan terlebih dahulu dari Pemerintah Suriah agar kerja sama yang terjalin antara UNICEF dengan Pemerintah Suriah tetap dapat berjalan dengan lancar tanpa keluar dari tujuan awal pemberian program bantuan, yaitu memberikan bantuan kemanusiaan untuk memastikan bahwa hak-hak dasar setiap anak terwujud melalui pendidikan dan perlindungan anak.

\section{Kendala dan Solusi Program No Lost Generation UNICEF}

Dalam laporan No Lost Generation menunjukkan sejak dimulainya program NLG, pendaftaran sekolah untuk pengungsi anak-anak Suriah telah meningkat dengan cepat. Namun, program NLG juga terdapat beberapa kendala, yaitu:

\section{Pelacakan pendanaan}

Melacak pendanaan secara akurat di keenam negara NLG untuk pilar NLG merupakan hal yang menantang, mengingat banyaknya sistem yang digunakan. Fakta bahwa sistem ini tidak digunakan secara rutin oleh semua pemangku kepentingan dan fakta bahwa fokus mereka terbatas pada perlindungan anak dan remaja, dan desain mereka yang berfokus pada kemanusiaan yang menghilangkan pendanaan bilateral, pinjaman lunak Bank Dunia dan pendanaan pembangunan lainnya. Oleh karena itu, untuk menanganinya NLG telah menggunakan konsultan ahli untuk mengeksplorasi opsi untuk menyiapkan sistem pelacakan keuangan yang lebih baik dengan mempertimbangkan pendanaan pembangunan dan mengatasi kesenjangan serta ketidakakuratan lain (Sacco, 2019).

\section{Kapasitas mitra yang masih terbatas}

Mitra tingkat regional sangat kewalahan mengingat urgensi dan besarnya respons yang sedang berlangsung. LSM khususnya mengalami defisit pendanaan. Ini membatasi sejauh mana setiap organisasi dapat berkomitmen dan berkontribusi pada upaya bersama (Sacco, 2019). Namun, penulis berpendapat hal tersebut dapat diatasi dengan tidak hanya menjalin relasi di kawasan regional saja. Misalnya, UNICEF bisa mengajak para pemuda di seluruh dunia untuk berpartisipasi dengan menjadi mitra kerja sama. Hal tersebut bisa dilakukan dengan mengadakan acara kampanye maupun kompetisi, seperti proyek penggalangan dana yang menggunakan blockchain bertajuk Game Changers. UNICEF dapat berinovasi mencari mitra kerja baru selain mitra LSM untuk memperluas peluang mendapatkan dana bantuan yang lebih banyak.

\section{KESIMPULAN}

Berdasarkan pada hasil analisis data dan pembahasan pada bahasan sebelumnya dapat ditarik kesimpulan sebagai berikut:

Pertama, pelaksanaan program No Lost Generation (NLG) memiliki tujuan yang jelas, yakni untuk melindungi keamanan dan masa depan keseluruhan generasi anak muda yang terdampak krisis di Suriah, termasuk para korban perekrutan tentara anak agar dapat hidup layak, berpendidikan, dan terbina. Tujuan NLG diperjelas dengan membaginya menjadi tiga fokus, yaitu pendidikan, perlindungan anak berusia di bawah 18 tahun, remaja berusia 10-19 tahun, dan pemuda yang berusia 15-24 tahun melalui fase I dan fase II.

Kedua, NLG merupakan program yang mempunyai penerapan strategi alternatif agar program ini memiliki peluang untuk dapat terealisasikan dengan cara mengaitkannya pada dua program lainnya yang bergerak dalam bidang advokasi, pencari suaka, dan kemanusiaan bagi korban di negara-negara yang terkena krisis Suriah, seperti Regional Refugee and Resilience Plan (3RP), dan Syria Humanitarian Response Plan (HRP).

Ketiga, NLG terbentuk dari hasil perumusan kebijakan dan program yang baik. Hal ini dibuktikan dengan adanya agenda rapat tahunan UNICEF melalui No Lost Generation Summit tahunan, dan dikeluarkannya hasil evaluasi perbaikan program dalam Annual Report tahunan.

Keempat, NLG adalah program hasil dari penyusunan yang matang antara UNICEF berkolaborasi dengan berbagai aktor baik negara 
maupun non-negara dalam mempermudah regulasi dan implementasi program. Keberhasilan dari kolaborasi ini adalah hasil laporan NLG pada tahun 2016 sampai 2018 lebih sistematis jika dibandingkan dengan tahun-tahun sebelumnya. Di mana NLG lebih memaksimalkan pemanfaatan sekolah publik, termasuk sekolah yang menerapkan doubleshift, kampanye Back to Learning, programprogram proteksi sosial lainnya.

Kelima, dalam memenuhi tercapainya tujuan NLG, UNICEF berusaha menyediakan sarana dan prasarana yang memadai, seperti melalui pada sektor pendanaan dan sumber daya manusia., Syrian Response Plan, kerja sama internasional, serta melalui penggalangan dana virtual.

Keenam, adanya pengawasan terhadap pengimplementasian NLG melalui sistem rutin dan survei khusus. Dari hasil tersebut dapat diperoleh data yang lebih spesifik berdasarkan wilayah, gender, tingkat ekonomi di mana dilaporkan melalui press release dan laporan tahunan.

Jadi, melalui keenam indikator efektivitas organisasi internasional di atas bisa dinilai bahwa bantuan dari UNICEF untuk Suriah berupa UNICEF No Lost Generation ini berjalan dengan efektif diukur dengan menggunakan indikator-indikator efektivitas yang digunakan oleh penulis dalam menganalisis penelitian tersebut.

\section{REFERENSI}

Fahham, A. M., \& Kartaatmaja, A. M. (2014). Konflik Suriah: Akar Masalah dan Dampaknya. Jurnal Politica, 5(1), 37-60. Retrieved January 6, 2021, from https://jurnal.dpr.go.id/index.php/politica/art icle/view/332

Alam, S. (2018). Peran United Nations Children's Fund (UNICEF) dalam Perlindungan Hak Anak - anak dan Pemuda Korban Perang di Suriah Melalui No Lost Generation Initiative Tahun 2016. Yogyakarta: Universitas Muhammadiyah Yogyakarta.

Auliya, A. A., \& Kusumawardhana, I. (2020). UNICEF and the WASH: Analisis Terhadap Peran UNICEF Dalam Mengatasi Masalah
Ketersediaan Air Bersih di India. Frequency of International Relations, 341 - 378, Vol 1, No 2.

Deovanka, S. R., \& Zulian, I. (2020). Analisis Kepentingan Nasional Amerika Serikat dan Rusia dalam Konflik Suriah (2013 - 2018). Jurnal FISK.

Erdina, T. V., \& Hariani, D. (n.d.). Analisis Efektivitas Organisasi Dalam Program Pelayanan Administrasi Terpadu Kecamatan (PATEN) Di Kecamatan Gunungpati Kota Semarang. Retrieved from media.neliti.com: https://media.neliti.com/media/publications/ 93138-ID-analisis-efektivitas-organisasidalam-pr.pdf

Fitria, I. (2017). United Nation Children's Fund (UNICEF) dalam Intervensi Kemanusiaan pada Konflik Suriah Tahun 2011-2015. JOM FISIP, 1-15.

Hennida, C. (2015). Rezim dan Organisasi Internasional. Malang: Intrans Publishing.

Ikbar, Y. (2014). Metodologi \& Teori Hubungan Internasional. Bandung: PT Refika Aditama.

Isawati. (2018). Sejarah Timur Tengah (Sejarah Asia Barat). Yogyakarta: Penerbit Ombak.

Kresnawan, G. (2017). UNICEF Ajak Gamer Bantu Krisis Kemanusiaan Suriah Dengan Mining Cryptocurrency. Retrieved from Gamebrott: https://gamebrott.com/unicefajak-gamer-bantu-krisis-kemanusiaansuriah-dengan-mining-cryptocurrency

Malahayati. (2015, October 31). Hukum Orrganisasi Internasional Sejarah dan Perkembangannya. Retrieved from Repository UNIMAL: https://repository.unimal.ac.id/2154/1/ORG ANISASI\%20INTERNASIONAL.pdf

Muhammad, R., Yani, Y. M., \& Sudirman, A. (2020). Analisis Konflik Arab Spring di Suriah. JUPIIS: Jurnal Pendidikan Ilmuilmu Sosial, 12(1), 113-122. doi:https://doi.org/10.24114/jupiis.v12i1.16 058

Mukhtar, U., \& Nashrullah, N. (2019, Januari 16). SNHR: Sebanyak 6.964 Warga Sipil Tewas di Suriah pada 2018. Retrieved from News:

https://www.republika.co.id/berita/internasio nal/timur-tengah/19/01/16/pleoqx320-snhrsebanyak-6964-warga-sipil-tewas-di-suriahpada-2018

Mutter, P. (2015, Februari 13). Kids on the Front Lines. Conflicts in the Middle East are increasingly pulling children into war. Retrieved from US. News: 
usnews.com/opinion/blogs/worldreport/2015/02/13/the-rise-of-child-soldiersin-syria

No Lost Generation Initiative. (2019, Maret 14). Investing in the Future: Protection and learning for all Syrian children and youth March 2019. Retrieved from reliefweb: https://reliefweb.int/report/syrian-arabrepublic/investing-future-protection-andlearning-all-syrian-children-and-youth

OCHA. (2017, December). 3RP Regional Refugeee \& Resilience Plan 2017 - 2018 In Response To The Syria Cases. Retrieved from Humanitarian Response Plan: https://www.humanitarianresponse.info/en/o perations/whole-of-syria/document/3rphrpjoint-chapeau-march-2017

Pattihua, A. R. (2017). Efektivitas Asean Intergovernmental Commission on Human Rights (AICHR) dalam Mengatasi HAM di Asia Tenggara. The 6th University Research Colloquium 2017, 513-530. Retrieved January 6, 2021, from http://journal.ummgl.ac.id/index.php/urecol/ article/download/1495/832/

Pikiran Rakyat. (2018, Maret 14). [Laporan Mendalam] Tentara Anak: Senjata Lebih Besar dari Tubuhku. Retrieved from PikiranRakyat.com: https://www.pikiranrakyat.com/internasional/pr-

01294831/laporan-mendalam-tentara-anaksenjata-lebih-besar-dari-tubuhku-421279

Ridho, M., Yani, Y. M., \& Sudirman, A. (2020). Analisis Konflik Arab Spring di Suriah. JUPIS: Jurnal Pendidikan Ilmu-Ilmu Sosial, 117.

Risnanin, M. (2014). Problematika Perekrutan Anak dalam Konflike Bersenjata dan Permasalahnya di Indonesia. Fiat Justisia Jurnal Ilmiah Hukum, Vol 8 No 3.

Sacco, A. (2019, November 12). The No Lost Generation (NLG) initiative in MENA. Retrieved from https://globalcompactrefugees.org/: https://globalcompactrefugees.org/article/no -lost-generation-nlg-initiative-mena
Sapir, D. G et all. (2018). Patterns of civilian and child deaths due to war-related violence in Syria: a comparative analysis from the Violation Documentation Center dataset, 2011-16. The Lancet Global Health, Vol 6, No 1, e103-e110.

Sirait, D. E. (2014). Peran UNICEF dalam Menangani Perekrutan Tentara Anak (Child Soldiering) di Myanmar (Tahun 2007-2013). Jom FISIP, 2(1), 1-13. Retrieved Januari 6, 2021, from https://jom.unri.ac.id/index.php/JOMFSIP/a rticle/download/2487/2421

Turner, L. (2018, Juni 26). Child Soldiers In Syria. Retrieved from Blog-Latest News: https://borgenproject.org/child-soldiers-insyria/

UNICEF. (2011). About UNICEF. Retrieved from https://www.unicef.org/about-unicef (20 Desember 2020)

UNICEF. (2015). Syria Education Sector Analysis. Retrieved from The effects of the crisis on education in areas controlled by the Government of Syria, 2010-2015: https://www.unicef.org/mena/media/6781/fil e/The $\% 20$ effects $\% 20$ of $\% 20$ the $\% 20$ crisis $\% 2$ 0on $\% 20$ education $\% 20$ in $\% 20$ areas $\% 20$ contr olled $\% 20$ by $\% 20$ the $\% 20$ government $\% 20$ of \%20Syria\%20(2010-2015).pdf.pdf

UNICEF. (2017). Syria Annual Humanitarian Situation Report, 2017 Humanitarian Results. Retrieved from unicef.org: https://www.unicef.org/mena/reports/syriaannual-humanitarian-situation-report

Widyawati, D. A., \& Widiani, R. (2019). Efektifitas UNICEF Country Programe 2009-2013 dalam Membantu Pemerintah untuk Melindungi Hak Anak Pasca Perang Sipil di Cote C'ivoire. Jurnal Internasional Relations Universitas Diponegoro. 